Оригинальные статьи / Original articles

https://doi.org/10.18619/2072-9146-2020-5-75-80 удК 634.13:631.541.11(470.3)

Сёмин И.В.

Долматов Е.А.,

Ожерельева 3.Е.

Федеральное государственное бюджетное научное учреждение Всероссийский научно-исследовательский институт селекции плодовых культур 302530, Россия, Орловская область, Орловский район, п/о Жилина

E-mail: semin@vniispk.ru

Конфликт интересов: Авторы заявляют об отсутствии конфликта интересов.

Для цитирования: Сёмин И.В., Долматов Е.А. Ожерельева 3.Е. Перспективы использования подвоя интенсивного типа для возделывания садов груши в условиях Центральной России. Овощи России. 2020;(5):75-80.

https://doi.org/10.18619/2072-9146-2020-5-75-80

Поступила в редакцию: 24.07.2020

Принята к печати: 23.09.2020

Опубликована: 25.09.2020

Igor V. Semin, Evgeny A. Dolmatov, Zoya E. Ozherelieva

Russian Research Institute of Fruit Crop Breeding v. Zhilina, Orel region, Russia, 302530

E-mail: semin@vniispk.ru

Conflict of interest. The authors declare no conflict of interest.

For citations: Semin I.V., Dolmatov E.A. Ozherelieva Z.E. Prospects for the use of intensive rootstock for cultivation of pear cultivars in the conditions of Central Russia. Vegetable crops of Russia. 2020;(5):75-80. (In Russ.) https://doi.org/10.18619/2072-9146-2020-5-75-80

Received: 24.07.2020

Accepted for publication: 23.09 .2020

Accepted: 25.09 .2020
Перспективы использования подвоя интенсивного типа для возделывания садов

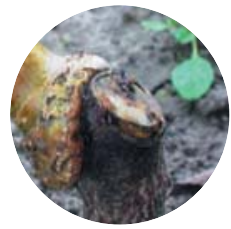
груши в условиях
Центральной России

Резюме

Актуальность. В центральных регионах России интенсивных грушевых насаждений нет по причине отсутствия карликовых подвоев интенсивного типа. Поэтому исследования в направлении получения зимостойких подвоев, обеспечивающих раннее вступление сада в пору промышленного плодоношения, ограничивающих рост растений и обеспечивающих быструю окупаемость вложенных затрат имеют высокую актуальность и широкие перспективы для применения.

Материалы и методы. Исследования проводили на базе лаборатории селекции и сортоизучения груши и нетрадиционных семечковых культур ФГБНУ ВНИИСПК. Объектом исследования стала айва обыкновенная селекции ФГБНУ ВНИИСПК. В 2008-2010; 2012-2014 годах изучали хозяйственно-биологические особенности айвы обыкновенной в качестве клоновых подвоев груши при размножении зелеными черенками. В 2018-2019 годах проводили исследования по применению семенных подвоев айвы обыкновенной в условиях питомника ФГБНУ ВНИИСПК.

Результаты. За период исследований отмечена высокая зимостойкость растений айвы обыкновенной в условиях Орловской области, а также ее высокая восстановительная способность в случае повреждений растений неблагоприятными факторами зимнего периода. Определена способность некоторых форм айвы обыкновенной хорошо размножаться зелеными черенками и обеспечивать высокий выход однородного посадочного материала. Установлена высокая семенная продуктивность айвы обыкновенной с получением семенных подвоев высокого качества. Определена хорошая совместимость некоторых сортов груши с айвой обыкновенной, их сдержанный рост и высокая скороплодность по сравнению с грушевым подвоем, а также получены предварительные данные по совместимости 11 сортов груши в условиях питомника и отмечены 4 несовместимых с айвой обыкновенной сорта.

Ключевые слова: айва обыкновенная, интенсивный подвой, сорта груши, совместимость сортов груши, семенной подвой.

\section{Prospects for the use of intensive rootstock for cultivation of pear cultivars in the conditions of Central Russia}

\section{Abstract}

Relevance. Unfortunately, there are no intensive pear plantations in the central regions of Russia due to the absence of intensive dwarf rootstocks. Therefore, the research aimed at obtaining winter-hardy rootstocks that provides early industrial fruiting of gardens, limits plant growth and gives a quick return on investment, is very important and can be applied in many different ways.

Materials and methods. The research was carried out in the laboratory of selection and variety study of pears and non-traditional pome crops of the Russian Research Institute of Fruit Crop Breeding (FSBSI VNIISPK). The object of the research was the common quince selected by FSBSI VNIISPK. In 2008-2010 and 2012-2014 we studied the economic and biological characteristics of the common quince as clonal pear rootstocks when propagated by green cuttings.

Results. The research results show high winter hardiness of the common quince plants in Oryol region, as well as their high regenerative capacity in case of damage caused by adverse winter conditions. It was determined that some types of common quince can be reproduced by green cuttings and provide a high yield of uniform planting material. The common quince has a high seed productivity that allows to get seedling rootstocks of high quality. Some pear cultivars demonstrate a good compatibility with the common quince, moderate growth and high early maturity in comparison with the pear rootstock; there are also preliminary data on compatibility of 11 pear cultivars in a nursery, and 4 cultivars that are incompatible with the common quince.

Keywords: common quince, intensive rootstock, pear cultivars, compatibility of pear cultivars, seedling rootstock. 


\section{Введение}

- руша оценивается как одна из лучших плодовых культур умеренного пояса и пользуется немалым спросом у населения. Интенсификация производства плодовой продукции расширила возможности ее возделывания, но вместе с тем поставило ряд сложных и важных задач перед производителями. Ежегодно в мировом плодоводстве сбор груши составляет 18-20 млн т плодов или 2-3 кг на душу населения в год. Ведущими производителями в мире выступают: в странах Азии - Китай, в странах Латинской Америки - Аргентина. Вместе они формируют основу мирового рынка груши. В России удельный вес производства плодов груши незначителен и составляет 65-68 тыс. т плодов или 0,45 кг на человека в год. При этом более $90 \%$ всех грушевых насаждений сосредоточено в южных регионах России и в частности в районах Северного Кавказа. И только около 2-3\% в более северных регионах, преимущественно в любительском садоводстве. На практике промышленное производство плодов груши в центральных регионах России по интенсивным технологиям практически не производится. Причинами тому является: первое недостаток скороплодных зимостойких сортов груши с продолжительным сроком хранения и высокими вкусовыми качествами плодов и второе - отсутствие карликовых подвоев интенсивного типа. Однако в последние годы в результате работы селекционеров получено немало сортов груши, отвечающих требованиям современного садоводства и пригодных к созданию интенсивных садов в Центральной полосе России. А вот подходящего подвоя, ускоряющего плодоношение сортов груши, ограничивающего рост растений и обладающего оптимальными хозяйственно-биологическими признаками, которые отвечают требованиям интенсивного садоводства, пока не найдено.

В связи с этим целью исследований стало изучение айвы обыкновенной селекции ФГБНУ ВНИИСПК в качестве подвоя для возделывания садов груши в условиях Центральной России по интенсивным технологиям.

\section{Объекты исследований}

Главным объектом исследования стали растения айвы обыкновенной селекции ФГБНУ ВНИИСПК, в качестве контроля выступали сеянцы груши лесной, широко используемые в качестве подвоев для груши в центральной России. Агротехника возделывания растений общепринятая.

\section{Материалы и методы}

Исследования проводили на базе лаборатории селекции и сортоизучения груши и нетрадиционных семечковых культур ФГБНУ ВНИИСПК в 2008-2019 годах. Опыт заложен в 2005 году на участке селекционной школки ФГБНУ ВНИИСПК по схеме 0,5 х 4,0 м. Сеянцы 2-го поколения зимостойких форм айвы обыкновенной селекции ФГБНУ ВНИИСПК были высажены в 1 ряд и являются в настоящее время маточником семенных подвоев айвы обыкновенной. В 2008-2010; 2012-2014 годах изучали хозяйственно-биологические особенности айвы обыкновенной в качестве клоновых подвоев груши при размножении зелеными черенками. Исследования проводили по методике «Метод зеленого черенкования» (Тарасенко, 1967). В 2018-2019 годах проводили исследования по применению семенных подвоев айвы обыкновенной в условиях питомника ФГБНУ ВНИИСПК. Посев семян производили по схеме 20 × 0,1 см. Изучение совместимости айвы обыкновенной с сортами груши производили в условиях питомника в 1-м и 2-м поле по схеме 0,2 × 0,9 м с использованием различных сортов и форм груши. Зимостойкость растений определяли, как в полевых условиях методом наблюдений, так и в лаборатории физиологии и устойчивости плодовых растений мето- дом искусственного промораживания растений и их частей в контролируемых условиях по методике «ускоренной оценки зимостойкости плодовых и ягодных растений» (Тюрина, Гоголева, 1978). Древесина однолетнего прироста является важнейшей проводящей тканью растений и наиболее уязвима к низким температурам в зимний период. Поэтому оценку давали по степени подмерзания древесины однолетнего прироста в соответствии с «Программой и методикой плодовых, ягодных и орехоплодных культур» (1999) по пятибалльной шкале. Искусственное промораживание проводили в климатической камере «ESPEC» PSL - 2KPH (с диапозоном температур $-70 \ldots 150^{\circ} \mathrm{C}$ и регулируемой влажностью). Программа учитывает четыре компонента зимостойкости:

- Формирование морозостойкости или устойчивость к ранним морозам после естественной закалки, когда растения находятся в состоянии органического покоя. Критическая температура $-30^{\circ} \mathrm{C}$.

- Максимальная морозостойкость (период окончания органического покоя); Критическая температура $-40^{\circ} \mathrm{C}$.

- Сохранение морозостойкости во время оттепелей (состояние вынужденного покоя. Критическая температу$\mathrm{pa}-25^{\circ} \mathrm{C}$.

- Способность восстанавливать морозостойкость при повторной закалке после оттепелей (в состоянии вынужденного покоя). Критическая температура - 350С.

Уход за опытными насаждениями проводился в соответствии с требованиями зональной агротехники.

\section{Результаты и их обсуждения}

Айва обыкновенная селекции ФГБНУ ВНИИСПК формирует многоствольный куст высотой от 230 до 410 см со средней и сильной побегообразовательной способностью (рис. 1). В среднем высота растений составляет 300-330 см. Цветение в условиях средней полосы России наблюдается во II и III декаде мая, что дает возможность айве обыкновенной в отличие от груши уйти от возвратных холодов. В ходе многолетних наблюдений за исключением отдельных лет, когда отмечались неблагоприятные погодные условия (2010 год; 2013 год и др.) айва показала высокую продуктивность, а существенных поражений болезнями растений не обнаружено.

В производстве плодов груши к подвоям интенсивного типа предъявляют особые требования, важнейшие из которых зимостойкость растений, способность хорошо размножаться, хорошая совместимость с сортами груши, способность ускорять вступление сортов в пору промышленного плодоношения и сдерживать рост растений.

Исследования в полевых условиях показали, что айва селекции ФГБНУ ВНИИСПК способна полноценно расти и развиваться в условиях средней полосы России без существенных повреждений неблагоприятными факторами зимнего периода. По нашим наблюдениям за период 2012-2020 годов значительного подмерзания растений не выявлено. Наиболее низкая температура за исследуемый период отмечалась зимой 2012-2013 годов и составила $39^{\circ} \mathrm{C}[1]$. При этом повреждение древесины, коры и почек айвы были не значительные и все растения быстро восстановились весной, активно вегетировали и сформировали полноценный урожай.

Искусственное промораживание однолетнего прироста айвы обыкновенной селекции ФГБНУ ВНИИСПК в контролируемых условиях, сопостовимое с критическими температурами зимнего периода средней полосы России в естественных условиях, показало незначительные повреждения побегов в начале зимы, когда после осенней закалки растения айвы в состоянии органического покоя могут переносить понижение температуры воздуха до $-30^{\circ} \mathrm{C}$ и в 
середине зимы до $-25^{\circ} \mathrm{C}$, когда на фоне оттепелей растения находятся в состоянии вынужденного покоя. Более существенные повреждения были отмечены при промораживании на максимальную морозостойкость $-40^{\circ} \mathrm{C}$ в период окончания органического покоя и промораживании на способность восстанавливать морозостойкость при повторной закалке после оттепелей $-35^{\circ} \mathrm{C}$ в конце зимы в период вынужденного покоя [1, 3]. В это время растения айвы наиболее уязвимы и могут подмерзать, однако на практике суровые зимы в умеренных широтах редкость.

При оценке морозостойкости корневой системы у всех исследуемых форм айвы обыкновенной селекции ВНИИСПК, при искусственном промораживании растений, отмечалась способность корней переносить критические температуры зимнего периода на уровне сеянцев груши лесной. Причём чем тоньше были корни подвоя, тем существеннее были повреждения. Скелетные корни более 4 мм толщиной практически не повреждались или имели незначительные повреждения [1-3]. В отличие от корней сеянцев груши на скелетных корнях, промороженных образцов айвы обыкновенной отмечались зачатки каллуса, что говорит об образовании новых корней, обуславливая тем самым высокую восстановительную способность корневой системы подвоя.

Изучалась также зимостойкость сортов груши привитых на семенных подвоях айвы обыкновенной и сеянцах груши путем искусственного промораживания однолетних побегов в контролируемых условиях при $-40^{\circ} \mathrm{C}$ (табл. 1). Это минимальная температура в зимний период отмеченная для условий средней полосы России на основе данных метеонаблюдений. В период окончания органического покоя растения показывают максимальную морозостойкость. В результате исследований установлено, что при использовании сеянцев айвы обыкновенной зимостойкость всех изучаемых сортов груши, совместимых с подвоем несколько выше, чем при использовании сеянцев груши.
Вероятно, это связано с биологическими особенностями айвы обыкновенной, способной накапливать сложные соединения с калием, а также сахара, повышающие зимостойкость растений в условиях хорошей совместимости с сортами груши.

Ранее во ВНИИСПК были выделены отборные формы айвы обыкновенной, которые хорошо размножаются зелёными черенками [4]. Степень укоренения зеленых черенков варьировало от 66 \% (32A-1-35) до 88,8 \% (32A-1-9) (табл. 2). Наиболее перспективными формами отмечены (32А-19; 32А-1-29 и 32А-1-26), с высоким процентом укоренения - 80-90\% [3]. Клоновые подвои имели достаточно разветвленную корневую систему с большим количеством (на 1-2\%) и толщиной скелетных корней (на 3-7\%), чем у семенных подвоев айвы обыкновенной, однако у семенных подвоев скелетные корни были более разветвленными и имели большее количество всасывающих корней соответственно, что благоприятно сказывается на условиях питания растений (Рис. 1).

Исследования показали, что в условиях питомника ФГБНУ ВНИИСПК при посадке 100 шт. зеленых черенков в парник в процессе их укоренения, доращивания в открытом грунте, окулировки сортами груши в полях питомника к моменту получения саженцев будет получено в среднем 50 60 шт. растений, которые будут обладать выровненностью (однородностью) посадочного материала, что является одним из важнейших условий интенсивного садоводства.

На практике гораздо более высокий выход подвойного материала даёт семенное размножение. Так, продуктивность 12 летнего семенного маточника айвы обыкновенной в питомнике ФГБНУ ВНИИСПК в среднем составляет 2-4 кг плодов на растение. Средний вес 1 плода 60-70 г (минимальное значение 30-35 г, максимальное 110 -130 г). Один плод айвы обыкновенной в среднем содержит 60-65 шт. семян, в то время как в плодах груши их всего 8-12 шт. (рис. 1).

Таблица 1. Зимостойкость сортов груши привитых почкой в боковой зарез на разных подвоях Table 1. Winter hardiness of pear cultivars grafted through a bud in a side cut on different rootstocks

\begin{tabular}{|c|c|c|c|c|c|c|}
\hline \multirow[b]{2}{*}{$\begin{array}{c}\text { Сорт } \\
\text { груши }\end{array}$} & \multirow[b]{2}{*}{ Подвой } & \multicolumn{5}{|c|}{ Степень повреждения однолетнего побега, балл } \\
\hline & & $\begin{array}{c}\text { Повреждение } \\
\text { почек, } \\
\text { балл }\end{array}$ & $\begin{array}{c}\text { Повреждение } \\
\text { коры } \\
\text { побега, } \\
\text { балл }\end{array}$ & $\begin{array}{c}\text { Повреждение } \\
\text { древесины } \\
\text { побега, } \\
\text { балл }\end{array}$ & $\begin{array}{c}\text { Повреждение } \\
\text { камбия, } \\
\text { балл }\end{array}$ & $\begin{array}{c}\text { Средний } \\
\text { балл } \\
\text { повреждений }\end{array}$ \\
\hline \multirow{2}{*}{$\begin{array}{l}\text { Белорусская } \\
\text { поздняя }\end{array}$} & Айва обыкновенная & 4,8 & 3,4 & 2,1 & 4,9 & 3,8 \\
\hline & Груша лесная & 5,0 & 4,8 & 3,6 & 5,0 & 4,6 \\
\hline \multirow{2}{*}{ Алая } & Айва обыкновенная & 3,6 & 4,0 & 2,3 & 4,8 & 3,7 \\
\hline & Груша лесная & 4,5 & 5,0 & 3,9 & 5,0 & 4,6 \\
\hline \multirow{2}{*}{$\begin{array}{l}\text { Памяти } \\
\text { Яковлева }\end{array}$} & Айва обыкновенная & 4,6 & 3,6 & 2,4 & 4,8 & 3,9 \\
\hline & Груша лесная & 4,9 & 5,0 & 4,3 & 5,0 & 4,8 \\
\hline
\end{tabular}

Таблица 2. Выход клоновых подвоев айвы обыкновенной при размножении зелеными черенками [4] Table 2. The yield of clonal rootstocks of the common quince when propagated by green cuttings [4]

\begin{tabular}{|c|c|c|c|}
\hline Форма & $\begin{array}{c}\text { Укореняемость } \\
\text { зеленых черенков, \% }\end{array}$ & $\begin{array}{c}\text { Приживаемость укорененных зеленых черенков } \\
\text { при доращивании в открытом грунте, \% }\end{array}$ \\
\hline $\mathbf{3 2 A - 1 - 9}$ & 88,8 & 81,2 \\
\hline $\mathbf{3 2 A - 1 - 2 9}$ & 81,4 & 80,0 \\
\hline $\mathbf{3 2 A - 1 - 2 6}$ & 81,0 & 88,2 \\
\hline
\end{tabular}




\section{ПОДВОИ ДЛЯ ГРУши:}

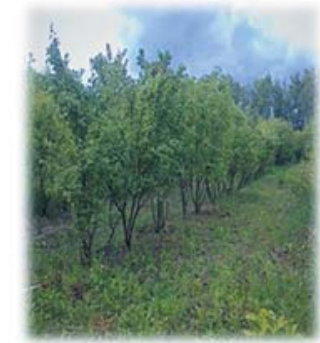

Маточные

растения

айвы

обыкновенной

для получения семян подвоев
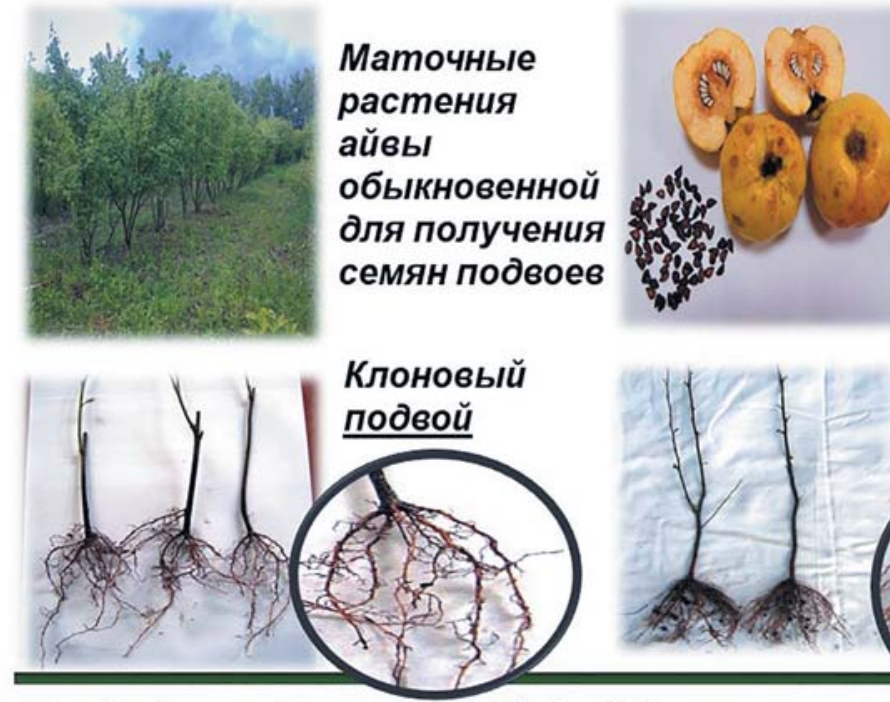

Binery,

Плоды и

семена айвы

обыкновенной

селекции

ВНИИспК

Плод айвы содержит от 50 до 120 семян.

Плод груши от 4 до 12 шт. семян.

ФГБНУ ВНИИ СЕЛЕКЦИИ ПЛОДОВЫХ КУЛЬТУР

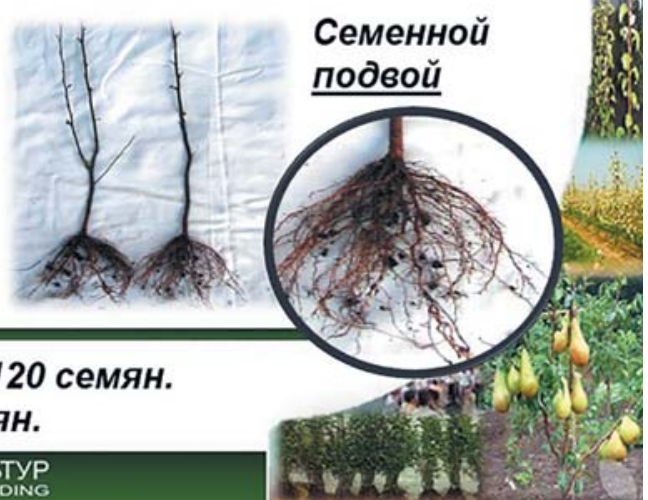

Рис. 1. Айва обыкновенная селекции ФГБНУ ВНИИСПК

Fig. 1. Common quince selected by the FGBNU VNIISPK

Семена айвы обыкновенной покрыты слоем слизи, которая составляет примерно 30-33\% от их массы. Перед выделением семян из плодов айвы семена сначала замачивают в воде, а затем отмывают от слизи для удобства дальнейшей работы. Масса 1000 шт. семян составляет 20-22 г. Как и у всех семечковых пород, семена айвы нуждаются в периоде стратификации, при низких положительных температурах во влажной среде, который составляет 85-90 дней.

По нашему мнению, наилучшим субстратом для стратификации семян является мох-сфагнум, который не только обеспечивает оптимальные условия увлажнения и аэрации во время стратификации, но и препятствует развитию различных заболеваний в этот период.

Семена в грунт лучше высевать слегка наклюнувшимися (появление зачатков корней) на глубину 1-2 см. Субстрат должен быть рыхлым и влагоёмким. В среднем всхожесть семян составляет 70-80\%. Айва культура влаголюбивая и достаточно требовательно к условиям питания. При посеве семян в полевых условиях и в условиях искусственных грядок с рыхлым субстратом наблюдались различия по всхожести и выходу подвойного материала (табл. 3). В условиях искусственных грядок отмечалось более высокая всхожесть семян и качество подвоев. К тому же применение искусственных грядок позволяет более эффективно использовать земельные площади в питомнике.

Одним из важнейших требований, предъявляемых к подвоям, является их совместимость с прививаемыми на них сортами. Признаки несовместимости могут проявиться как в питомнике, так и в последующие годы произрастания в саду.

В первую очередь, совместимость сорта с подвоем определяется, начиная уже в питомнике по трём основным показателям [4]:

1) Точечная болезнь подвоя - проявляется часто в виде слабых приростов, мелких суховатых листьев и явным образованием некрозов в древесине и на коре подвоев.

2) Голодание подвоя. Проявляется чуть позже, чем точечная болезнь и выражается в сравнительно раннем окончании поступательного роста побегов, преждевременное покраснение и осыпание листьев и в месте прививки часто образуется наплыв.

3) Непрочное срастание древесины сорта и подвоя. Может проявляться не сразу и иметь первое время доста-

Таблица 3. Всхожесть семян и качество подвоев айвы обыкновенной при посеве

в полевых условиях и в условиях искусственных грядок (2008; 2019 годы)

Table 3. Germination seeds and quality of common quince rootstocks when sown in the field and in man-made beds (2008; 2019)

\begin{tabular}{|l|c|c|}
\hline \multicolumn{1}{|c|}{ Параметры } & В полевых условиях & В условиях искусственных грядок \\
\hline Всхожесть, \% & $50-70$ & $70-80$ \\
\hline Средняя длина прироста, см & 15 & 20 \\
\hline Толщина прироста, мм & $1,0-1,4$ & $1,2-1,6$ \\
\hline Количество скелетных корней, шт. & $2-4$ & $3-5$ \\
\hline Длина скелетных корней, см & $7-9$ & $12-14$ \\
\hline Толщина скелетного корня, мм & $2,2-2,7$ & $2,7-3,2$ \\
\hline Порядок ветвления & $1-2$ & $3-4$ \\
\hline Толщина корневой шейки, мм & $3-4$ & $5-6$ \\
\hline Средний выход подвоев, \% от всхожих семян & 80 & 90 \\
\hline
\end{tabular}


Таблица 4. Совместимость айвы обыкновенной с сортами груши Table 4. Compatibility of common quince with pear cultivars

\begin{tabular}{|l|l|l|}
\hline Хорошо совместимые сорта и формы груши & Удовлетворительно совместимые сорта и & Несовместимые сорта и формы груши \\
\hline \begin{tabular}{l|l} 
Есенинская & \multicolumn{1}{|c|}{ формы груши }
\end{tabular} \\
$\begin{array}{l}\text { Тютчевская } \\
\text { Муратовская }\end{array}$ & Пнушка & Орловская красавица Орловская летняя \\
Алая & Пкомятная & \\
\hline
\end{tabular}

Памяти Яковлева

Белорусская поздняя

Вставочный подвой -

яблоне-грушевый гибрид № 818

Вставочный подвой - сеянец уссурийской груши № 20-11

точно сильный и хороший рост. Однако через некоторое время побеги могут отламываться и излом в месте прививки гладкий, без волокон.

В предварительно проведенных исследованиях сотрудниками ФГБНУ ВНИИСПК была установлена хорошая совместимость в питомнике 6 сортов груши среди которых Алая, Белорусская поздняя, Есенинская, Муратовская, Памяти Яковлева, Тютчевская и др. с семенными подвоями айвы обыкновенной [3]. В питомнике все сорто-подвойные комбинации показали хорошее срастание с подвоем и активный рост. Также установлено, что сорта Аннушка и Памятная хотя и мели прочное срастание с подвоем и не показали явных признаков несовместимости, но при этом не было получено в этой комбинации ни одного стандартного саженца груши, что обусловлено слабым развитием привоя (табл. 4). Сорта Чижевская и Красавица Черненко показали хороший рост привоя в комбинациях с айвой обыкновенной, но также в отличии от остальных комбинаций развитие на груше было значительно сильнее, чем на айве. Наблюдения показывают, что у сортов Памятная и Аннушка слабое развитие привоя на всех вариантах опыта наблюдалось в течение всего сезона, а у сортов Чижовская и Красавица Черненко в начале вегетации отмечался активный рост побегов, который после начала одревеснения побегов значительно ослабевал. Возможно у этих сортов имеет место частичная несовместимость, когда отдельные ткани привоя ввиду различий в биологическом строении или метаболизме не могут полностью срастись с тканями подвоя, что приводит к нарушению физиологических процессов в растении.

яблоне-грушевый гибрид №818 показал хорошее срастание с айвой обыкновенной и интенсивный рост, а также очень активное ветвление в течение всей вегетации и может рассматриваться в качестве совместимой вставки для несовместимых с айвой обыкновенной сортов груши (рис. 4). К тому же гибрид сам является достаточно слаборослым подвоем для сортов груши и имеет достаточно высокую зимостойкость для средней полосы России.

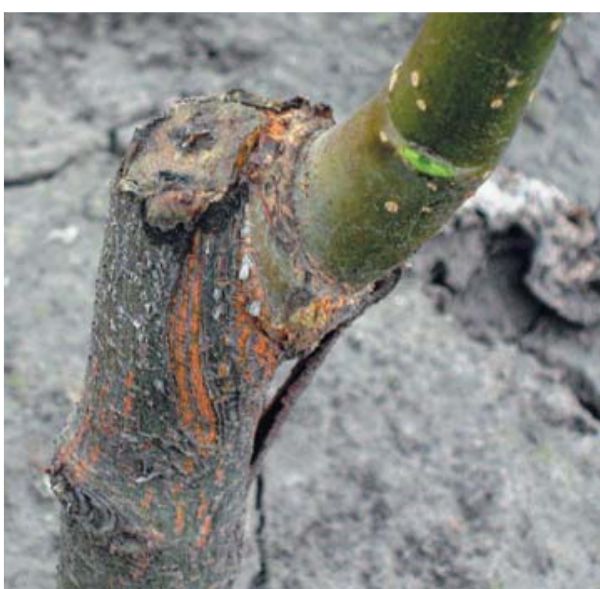

Рис. 2. Есенинская на айве Fig. 2. Yeseninskaya grafted to quince

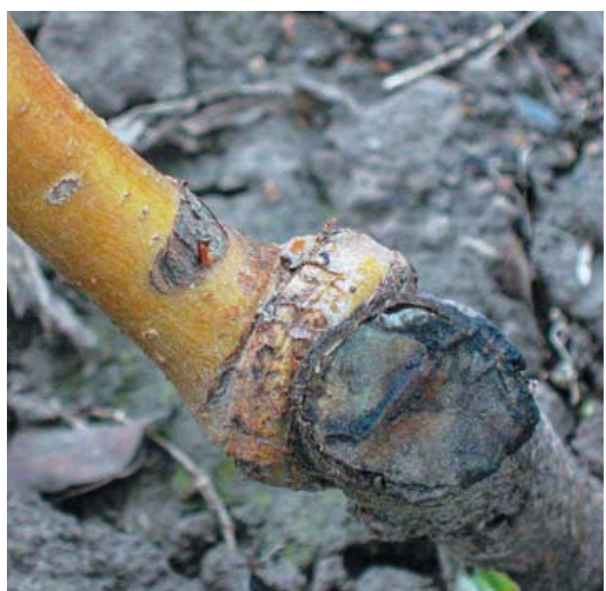

Рис 5. Орловская красавица на айве

Fig. 5. Oryol beauty grafted to quince

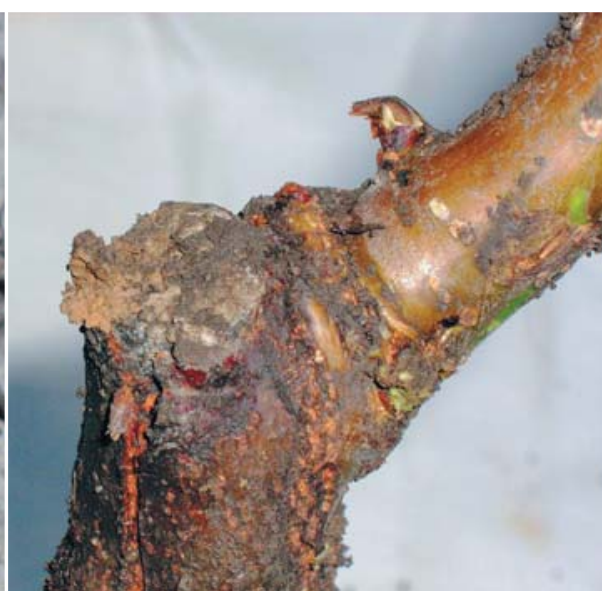

Рис. З. Муратовская на айве

Fig. 3. Muratovskaya grafted to quince

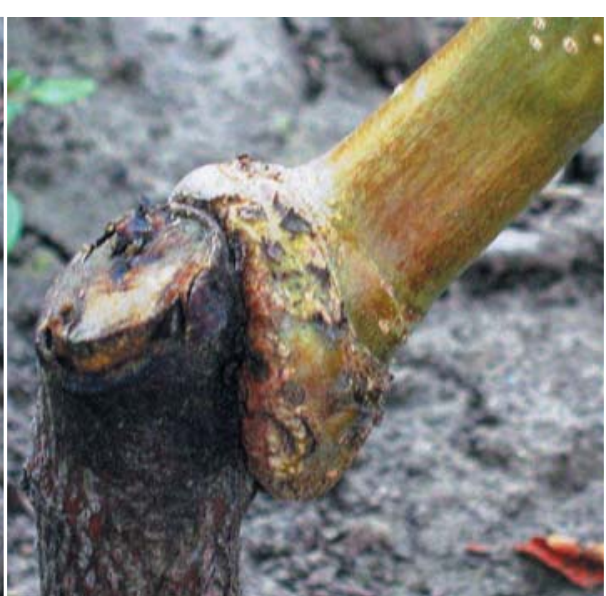

Рис. 6 Орловская летняя на айве

Fig. 6. Oryol summer type grafted to quince

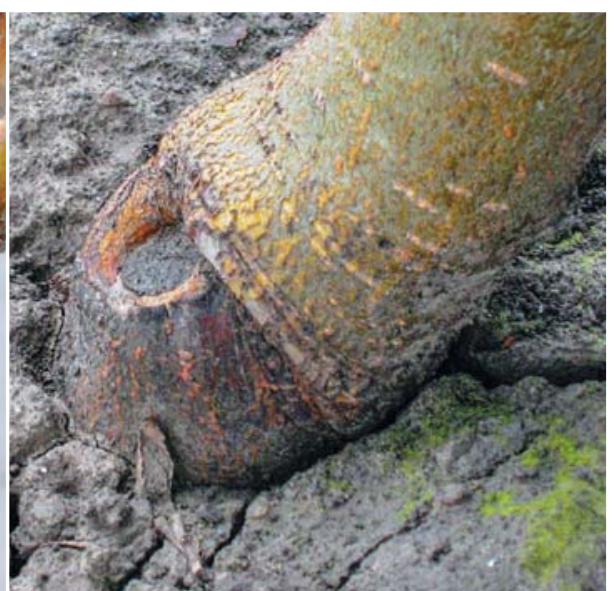

Рис. 4. Яблоне-грушевый гибрид № 818 на айве

Fig. 4. Apple-pear hybrid No. 818 grafted to quince

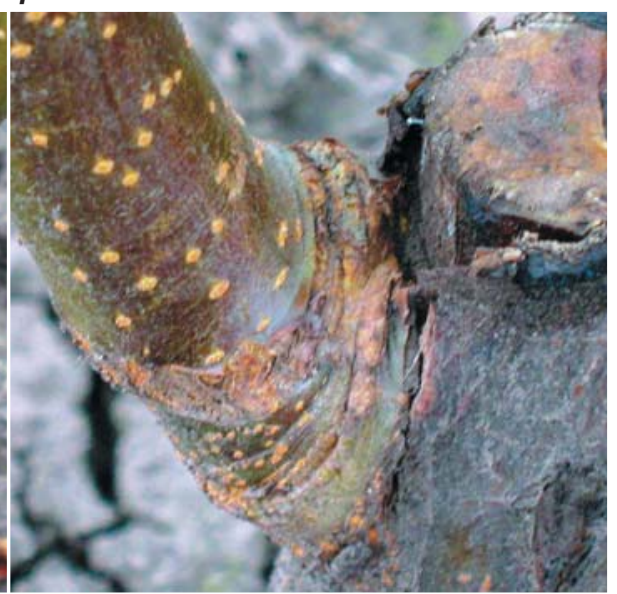

Рис 7. Русановская

на айве

Fig. 7. Rusanovskaya grafted to quince 
Явные признаки несовместимости отмечались при прививке на айву сортов груши Орловская красавица, Орловская летняя, Скороспелка из Мичуринска, Русановкая (рис. 5; 6; 7) и зимостойкий сеянец апомиктической груши уссурийского происхождения № 20-11, который рассматривался нами в качестве вставочного подвоя (таб. 4). В этих комбинациях наблюдались наплывы и отломы в месте срастания с подвоем, преждевременное изменение окраски листьев и их раннее опадение, а также интенсивное образование поросли в зоне подвоя. Часто кора привоя меняла окраску приобретая оттенки красного цвета сразу после одревесневания побегов в середине лета и фенотипически отличалась от оригинала. У сорта Русановская и сеянца №20-11 наблюдалось угнетение растений по сравнению с комбинациями при использовании грушевого подвоя. Очевидно эти сорта нуждаются в посреднике (вставочном подвое) при прививке на айву обыкновенную.

Краткое описание наиболее перспективных сортов груши при прививке на айвовые подвои, которые могут также представлять промышленное значение.

Алая - новый сорт селекции ВНИИСПК. Показал прочное срастание с айвой и довольно мощный рост в питомнике и в последующие годы. Первые плоды появляются уже на 3-й год после посадки в сад. В 10-летнем возрасте высота деревьев не превышает 2,0-2,5 м.

Белорусская поздняя - зимний сорт селекции Белорусского НИИ плодоводства. Имеет прочное срастание с подвоем и мощный рост в питомнике. Плоды появляются на 4 год после посадки. Высота деревьев в 9 летнем возрасте не превышает 1,7-2,0 м.

Есенинская - осенний сорт селекции ВНИИСПК. Имеет прочное срастание с айвой обыкновенной, более сильный рост побегов и лучшее их ветвление в питомнике по

\section{Об авторах:}

Сёмин Игорь Валерьевич - кандидат с.-х. наук,

научный сотрудник, лаборатория селекции и

сортоизучения груши и нетрадиционных семечковых культур

Долматов Евгений Алексеевич - доктор с.-х. наук,

ведущий научный сотрудник, лаборатория селекции и

сортоизучения груши и нетрадиционных семечковых культур

Ожерельева Зоя Евгеньевна - кандидат с.-х. наук, ведущий научный сотрудник, лаборатория физиологии устойчивости плодовых растений, https://orcid.org/0000-0002-1730-4073, ResearcherID: C-7380-2017

\section{- Литература}

1. Борисова О.Н., Долматов Е.А. Морозостойкость корневой системы перспективных клоновых подвоев для груши. Успехи современной науки. 2017;(7):11-13.

2. Борисова О.Н., Долматов Е.А. Совместимость новых форм айвы селекции ФГБНУ ВНИИСПК с сортами груши. Селекция и сорторазведение садовых культур. 2016:3(2):6-10.

3. Долматов Е.А., Сидоров А.В., Баранов Р.В. Зимостойкость новых форм айвы обыкновенной в связи с использованием ее в качестве семенного подвоя груши. Проблемы агроэкологии и адаптивность сортов в современном садоводстве России. Орел: Издательство ВНИИСПК, 2008:60-64 4. Долматов Е.А., Борисова О.Н. Хозяйственно-биологические особенности форм айвы обыкновенной селекции ВНИИСПК в качестве подвоев для груши. Селекция и сорторазведение садовых культур. 2018;5(1):20-25.

5. Коровин В.А. Причины несовместимости при прививках плодовых растений. Совместимость привоя и подвоя яблони. М.: Колос. 1979:3-119.

6. Программа и методика сортоизучения плодовых, ягодных и орехоплодных культур. (Под общей редакцией академика РАСХН Е.Н. Седова и доктора сельскохозяйственных наук Т.П. Огольцовой). Орел: издательство Всероссийского научно-исследовательского института селекции плодовых культур. 1999:608 с

7. Тарасенко М.Т. Размножение растений зелеными черенками. М.: Колос 1967: 352 c

8. Тюрина М.М., Гоголева Г.А. Ускоренная оценка зимостойкости плодовых и ягодных растений. Методические рекомендации. Москва: НИИ садоводства.:1978:48 с сравнению с использованием грушевого подвоя (рис. 2). На айве сорт начал плодоносить на 3-й год после посадки, а при интенсивном уходе первое цветение растений отмечалось уже в питомнике на 2-й год. Высота дерева в 10-летнем возрасте не превышает 2,0-2,5 м.

Муратовская - осенний сорт селекции ВНИИСПК. Срастание с подвоем прочное. Плодоносить начинает на 4 год после посадки (рис. 3). Высота растений в 10 летнем возрасте не превышает 2,4 м.

Памяти Яковлева - раннеосенний сорт получен во Всероссийском научно-исследовательском институте генетики и селекции плодовых растений им. И.В. Мичурина. Имеет довольно прочное срастание с айвой, но также отмечается образование наплыва в месте прививки. Который с возрастом уменьшается. При этом других признаков несовместимости не отмечается. Сорто-подвойная комбинация с айвой обыкновенной показала уже в питомнике более мощный рост и ветвление, чем при прививке на грушу. Плодоносить начинает на 3-й год после посадки. Высота деревьев в 12 летнем возрасте не превышает 2 м.

Тютчевская - раннеосенний сорт селекции ВНИИСПК. Срастание с подвоем довольно прочное, хотя и наблюдается небольшой наплыв. Сорт при прививке на айву начинает плодоносить на 4-й год после посадки. В 12-летнем возрасте растения не превышают 1,5-2,2 м.

Все сорта, привитые на айвовые подвои, показавшие хорошую совместимость имеют более высокую побегообразовательную способность, чем при прививке на семенные подвои груши.

Таким образом, айва обыкновенная представляет большой интерес для всестороннего изучения в качестве перспективного подвоя груши для производства плодов по интенсивным технологиям как в средней полосе России, так и в зонах рискованного земледелия.

\section{About the authors:}

Igor V. Semin - Cand. Sci. (Agriculture),

Research Scientist, the laboratory of selection

and variety study of pears and non-traditional pome crops

Evgeny A. Dolmatov - Doc. Sci. (Agriculture)

Leading Research Scientist, the laboratory

of selection and variety study of pears and non-traditional pome crops

Zoya E. Ozherelieva - Cand. Sci. (Agriculture),

Leading Research Scientist, the laboratory of physiology of fruit plant resistance, https://orcid.org/0000-0002-1730-4073, ResearcherID: C-7380-2017

\section{- References}

1. Borisova O.N., Dolmatov E.A. Frost resistance of the root system of potentially productive clonal rootstocks for pear trees. Success of modern science. 2017;(7):11-13. (In Russ.)

2. Borisova O.N., Dolmatov E.A. Compatibility of new types of quince selected by FGBNU VNIISPK with pear cultivars. Selection and cultivation of garden crops. 2016;3(2):6-10. (In Russ.)

3. Dolmatov E.A., Sidorov A.V., Baranov R.V. "Winter hardiness of new types of the common quince used as a seed rootstock of pear trees". Problems of agroecology and adaptability of cultivars in modern gardening in Russia. Oryol: VNIISPK Publishing House. 2008:60-64. (In Russ.)

4. Dolmatov E.A., Borisova O. N. "Economic and biological features of the common quince selected by VNIISPK and used as a rootstock for pear trees". Selection and cultivation of garden crops. 2018;5(1):20-25. (In Russ.)

5. Korovin V.A. "Reasons for incompatibility of grafted fruit plants" Compatibility of apple tree scions and rootstocks. M.: Kolos. 1979:3-119. (In Russ.)

6. "Program and methodology for the variety study of fruit, berry and nut crops". edited by E.N. Sedov, Science Academy Member of RASHNE, and T.P. Ogoltsova, Doctor of Agricultural Sciences. Oryol: publishing house of the AllRussian Scientific Research Institute for Selection of Fruit Crops.:1999:608 p. (In Russ.)

7. Tarasenko M.P. Plant propagation by green cuttings. M.: Kolos. 1967:352 p. (In Russ.)

8. Tyurina M.M., Gogoleva G. A. Accelerated assessment of winter hardiness of fruit and berry plants. Guidelines. Moscow: Research Institute of Gardening. 1978:48 p. (In Russ.) 